\title{
Between a Rock and a Hard Place: Developing organizational and institutional fit in MNE subsidiary political strategy in contexts of institutional upheaval
}

Dorottya Sallai, University of Greenwich, D.Sallai@greenwich.ac.uk

Gerhard Schnyder, Loughborough University London, G.Schnyder@lboro.ac.uk

\begin{abstract}
Recent corporate political activities (CPA) studies applying the "fit paradigm" found
\end{abstract} that foreign subsidiaries' political capabilities in emerging markets are shaped not just by host country- but also by home country institutions: Subsidiaries of multinational enterprises (MNEs) need to develop CPA that "fit" parent political capabilities. Yet, this literature neglects that this "organizational fit" requirement goes together with an "institutional fit" requirement between subsidiary CPA and the host institutional environment. Achieving this dual fit is particularly difficult in very volatile institutional host environments where the value of political capabilities changes rapidly. In such environments subsidiaries face a dilemma between the decreasing "institutional fit" of easily transferable capabilities and the lack of "organizational fit" of necessary "sticky," local ones. To understand how firms deal with this dilemma, we develop a typology of political capabilities that takes into account their varying transferability/stickiness and their dynamic institutional contingency in the host country. Our empirical study of Hungary shows that MNEs even from institutionally very different economies can successfully transfer political capabilities to develop effective CPA in a radically volatile political environment. Yet, as political risk becomes discontinuous, this strategy may reach its limits. [190 words]

Keywords: nonmarket, strategies, MNE subsidiaries, capabilities, corporate political activities (CPA), transferability 


\section{Introduction}

The corporate political activities (CPA) literature emerged in the context of developed countries (Hillman et al., 2004; Hillman and Hitt, 1999) and has little to say about how the institutional context of emerging economies affects CPA (Deng and Kennedy, 2010; Mondejar and Zhao, 2013; White et al., 2018; Zhang et al., 2016). Yet, CPA is particularly important in emerging market economies where the boundaries between the economic and the political domain are blurry (Carney et al., 2016; Luo, 2007; Nell et al., 2015; Zhang et al., 2016) and institutional change is frequent and often radical (Oh and Oetzel, 2017; Young et al., 2008). Companies may have to develop political 'coping' strategies to deal with such institutionally volatility political environments (Danisz et al., 2010; Darendeli and Hill, 2016; Dieleman and Boddewyn, 2012; Dieleman and Sachs, 2008; Iankova and Katz, 2003). Little is known about how foreign subsidiaries develop such local nonmarket strategies (Carney et al., 2016; White et al., 2018).

Recent studies have shown that foreign subsidiaries' host country political strategies are to an important extent determined by their home country institutional environment (White et al., 2018). Applying the "fit paradigm" (Brouthers et al., 2000; Luo \& Park, 2001; Zajac et al., 2000) they suggest that "subsidiary performance outcomes may be affected by fit between an MNE parent's capabilities, developed as a means to successfully deal with home country institutions, and foreign subsidiary strategic practices abroad" (White et al., 2018: 2). Yet, while acknowledging the need for internal "fit" between parent and subsidiary capabilities and strategies, in terms of institutional pressures they either focus on home country institutions (White et al. 2018) or host country ones (Hillman \& Wan, 2005), but do not acknowledge the simultaneous influence of both. Yet, MNEs are embedded in multiple institutional contexts and their political strategies are therefore simultaneously influenced by home- and host country contexts (Kostova and Zaheer, 1999; Kostova and Roth, 2002). Zajac 
et al. (2001) have previously argued that strategic fit needs to be conceptualized as a multidimensional concept encompassing organizational strategy, organizational capabilities, and the organization's environment. This creates “a potential tension in a firm's seeking a fit between its strategy and its environmental situation vs. a fit between its strategy and its unique competencies." (Zajac et al., 2001: 430). Applied to the MNE and acknowledging that political capabilities are partly shaped by the institutional environment (Whitley, 2007), this implies that effective CPA requires the subsidiary to simultaneously strive for "strategic fit" with institutionally-structured parent capabilities and "fit" with the host country environment. We call the former "organizational fit" and the latter "institutional fit." Adding these two dimensions allows us to further develop the "fit paradigm" as applied to CPA. Indeed, this conceptualization raises two further issues that the extant literature does not explicitly address: firstly, the "fit paradigm" is based on the explicit assumption that political capabilities are transferable across borders (Carney et al., 2016; Holbourn \& Zelner, 2010). Yet, this may not be the case of all political capabilities (cf. Hill \& Wan, 2005). Indeed, it has been argued that some political capabilities are "developed based on the firm's experience in a specific country and so may not be portable across geographies" (Doh et al., 2012: 31; also Bonardi et al., 2006). From the latter perspective, transfer of institutionally-structured political capabilities can be expected to be difficult.

Secondly, existing studies on political capability transfer and fit - while acknowledging the temporal nature of capability development in the home context (Carney et al., 2016; White et al., 2018) - do not sufficiently acknowledge the implications of the instable institutional environment in the host context. Indeed, the very nature of "unstable" or "weak" environments implies that institutional pressures are in constant flux (Young et al., 2008). The literature has shown that in volatile environments political capabilities may change in value dramatically when the institutional environment changes (Darendeli \& Hill, 
2016; Henisz and Delios, 2004; Leuz and Oberholzer-Gee, 2006; Oetzel and Oh, 2014;

Siegel, 2007; Sun et al., 2010). Therefore, it is crucial to pay more attention to the dynamic nature of fit between capabilities, strategies, and institutions (cf. Zajac et al., 2001).

In this paper, we seek to contribute to the "fit paradigm" by proposing an enhanced typology of political capabilities that connects the question of the "institutional structuring" (Whitley, 2007) of political capabilities to their transference across borders and their value to the subsidiary in terms of their fit with the host environment. We seek to answer two research questions: (1) How does the effectiveness and hence value of different types of foreign subsidiary political capabilities change during radical institutional change? (2) How do foreign subsidiaries manage to leverage different types of political capabilities through transfer or local development to adapt their CPA to the radically changing host environment?

We argue that different institutional environments require and therefore lead firms to develop different types of capabilities, whose inherent characteristics also determine the degree to which they are transferable from parent to subsidiaries. Rather than assuming that all political capabilities are equally transferable, we draw on the "practice transfer" literature (Edwards et al., 2015; Gamble, 2010; Jensen and Szulanski, 2004; Kostova, 1999) and provide an explicit theorization of the determinants and degree of the transferability of political capabilities.

Our empirical context is Hungary under Viktor Orbán’s governments since 2010. During this period, firms operating in Hungary have experienced a phase of radical institutional change that is often referred to as "institutional backsliding." Institutional backsliding is characterized by a "reversal" of the transition process from a socialist economy to a Western-style market economy and is characterized by an increasing concentration of state power, the personalization of economic and political exchanges, and the undermining of rules-based forms of economic transactions (Sallai \& Schnyder, 2015). As such, Hungary 
constitutes a politically instable environment where the rules of the game are deliberately kept in constant flux.

We compare the political strategies of MNE subsidiaries from developed countries (DMNEs) with domestic Hungarian firms (DFs). While MNE subsidiaries draw on a wide range of transferred and locally-developed capabilities, DFs can only draw on locallydeveloped ones. As such, they constitute a "control group" in our natural experiment research design. While the Western home countries of MNE subsidiaries vary in institutional characteristics too, they share the basic feature of a home institutional environment that contrary to the Hungarian host environment - provides a certain level of "generalized trust," which is crucial to make rule-based, arm's-length transactions outside of one's personal network possible (Chen \& Deakin, 2015; Peng, 2003; Whitley, 2007).

Based on our empirical case, we develop propositions regarding the effectiveness of transferred political capabilities and their impact on MNE subsidiary competitive advantage in a changing environment. We answer recent calls for longitudinal qualitative studies on political capabilities that allow us to trace the development of political capabilities and their co-evolution with their environment (Sun et al., 2015: 1059).

We contribute to the resource-based view approach to CPA (Frynas et al., 2006; Hillman and Hitt, 1999; Lawton et al., 2013a; Oliver and Holzinger, 2008), by enhancing existing typologies that do not take into account the question of the transferability - or its opposite "stickiness," defined as the difficulty with which organizational practices or routines can be transferred across borders (Jensen and Szulanski, 2004; Szulanski, 1996) - and the related question of the contingent value of political capabilities in fast-changing institutional environments. We also contribute to the recent literature on transfer of political capabilities that considers the "strategic fit" between subsidiary nonmarket strategy with parent company capabilities and home country institutions key to the success of nonmarket strategies (White 
et al., 2018). Our study suggests that a second type of fit is equally important, namely "institutional fit" between subsidiary CPA and host country institutional environment. Figure 1 summarizes our model (see Appendix 1). As such, our study makes an important contribution to the understudied question of how institutional differences across countries shape MNE political activities (Doh et al., 2012: 27; Liedong et al., 2015; White et al., 2018). We also make an important empirical contribution by gathering unique primary data about CPA through semi-structured interviews with top level managers in an emerging market economy with a very volatile political environment. Such studies remain scarce, which has hampered theorization (Lux et al., 2011; White et al., 2018).

\section{Literature and Theory}

Like organizational practices and structures in general, CPA tends to co-evolve with its institutional environment (Doh et al., 2012; Feinberg et al., 2015; Hillman and Wan, 2005; Lux et al., 2011), as institutions play an important role in structuring the type of political capabilities a firm develops (Bonardi et al, 2006; Holbourn and Zelner, 2010; White et al., 2018; generally Whitley, 2007). In the case of MNEs and their subsidiaries, this implies that each subsidiary is exposed to two institutional environments - the home and the host country ones (Kostova \& Roth, 2002). Existing CPA studies have either focused on how this "institutional duality" forces companies to achieve internal legitimacy - i.e. strategic fit between host and parent political strategy - at the same time as external legitimacy in the host environment (Hillman \& Wan, 2005), or how home country institutions shape parent capabilities with which subsidiary political strategies need to strategically fit (White et al., 2018). Curiously, the existing literature has not considered the specific challenge that the dual constraint from host and home institutions posits in terms of legitimacy and fit. Indeed, the institutional structuring of capabilities by the home and the host environment imply that the subsidiary's capabilities will be a mixture of transferred capabilities shaped by the home 
context and locally-developed ones shaped by the host context (cf. Gamble, 2010). What this literature overlooks, however, is that the transference of home country political capabilities to a host setting meets a dual challenge; namely to achieve simultaneously "organizational fit" with parent political capabilities and "institutional fit" with the host country institutional environment. The challenge to achieve "institutional fit" is enhanced in volatile host environments such as developing countries (Carney et al., 2016; White et al., 2018).

An effective political strategy therefore will need to combine transferred and locallydeveloped capabilities in a way that both satisfies "organizational fit" with the parent company and "institutional fit" with the host environment. Our framework is based on the assumption that a theory of political capabilities therefore needs to include more systematically the determinants of transferability of political capabilities across borders and the changing "value" - in terms of institutional fit - of political capabilities in the changing host setting.

\subsection{The fit paradigm: Organizational-and institutional fit of political capabilities}

The "fit paradigm" (Brouthers et al., 2000; White et al., 2018) - often implicitly comprises two analytically distinct claims: firstly, that companies need to seek a fit between their strategies and the companies' distinctive capabilities; secondly, that the strategy and the capabilities it is based on also need to match the companies' external environment. This constitutes what Zajac et al. (2001) call the multi-dimensional nature of the concept of "strategic fit." We call the former phenomenon "organizational fit" and the latter “institutional fit." White et al.'s (2018) useful attempt to apply the "fit paradigm" to political strategies, while explicitly acknowledging the institutional structuring of capabilities, focuses on the "organizational fit" of subsidiary strategies with parent company capabilities, but neglects the "institutional fit" between subsidiary political strategy and host institutional environment. Hillman and Wan (2005), on the other hand, do touch upon the "institutional 
fit" between host country context and subsidiary political strategy, but the question of which strategies rely on easily transferable capabilities and which ones on "sticky" ones is not systematically theorized. To fill this gap in the literature, two questions need to be answered: What types of political capabilities do different institutional contexts require? What determines their transferability across national boundaries? We tackle them in turn.

\subsection{Institutional contexts and fitting capabilities}

Most of the extant CPA literature focuses on developed economies (Bonardi, 2011; Hillman et al., 2004; Oliver and Holzinger, 2008) and assumes a fundamentally stable political environment. Yet, the notion that political capabilities and strategies differ across institutional settings is well-established. The most basic distinction here is between institutional environments that support generalized arm's-length exchange via markets based on a strong legal system of public ordering, which we call rule-governed contexts (cf. Chen \& Deakin, 2015; Whitley, 2007; Peng, 2003), and systems where economic exchange is mainly based on private ordering through relationships as personal mechanisms to generate trust (e.g. Carney et al., 2016; Peng 2003). To be sure, there is a great variety of national institutional systems within each one of these categories (Witt et al., 2017; Fainshmidt et al., 2017). Yet, the distinction between rule-governed and relationship-based systems captures a fundamentally different way of transacting, that has crucial implications for the question of (political) capabilities (Whitely, 2007).

Relationship-based systems often exist in more volatile and uncertain environments than rule-based ones (Peng, 2003; Young et al., 2008). Yet, we can further distinguish such volatile and uncertain political environments where risks are continuous - e.g. corruption (Cuervo-Cazurra, 2008) - and hence relatively predictable for firms, from environments where political risk become "discontinuous" and hence unpredictable, e.g. revolutions and military coups (Oetzel and Oh, 2014). Extremely volatile political environments, where state 
intervention becomes completely arbitrary, come close to what is described as "discontinuous risk."

These different institutional contexts - rule-governed stable, relationship-based predictable, relationship-based volatile - favor different types of CPA. In rule-governed systems, where transactional market exchanges are the norm, CPA is "largely about legal, firm-level engagement with institutionalized political actors and structures" (Lawton et al., 2013 a: 87). CPA is a professionalized, issue-driven activity, that follows fairly transparent and clear "rules of the game" (Griffin and Dunn, 2004; McGrath, 2005; Van Schendelen, 2012; Thomson and John, 2007; Beyers et al., 2008) and which is mostly viewed as an "essential, legitimate and distinguishable activity, which supplements business activity" (Hadjikhani and Ghauri, 2006: 391). Lobbying is managed within formal institutions - based on arm's length transactions - and the organizational capabilities of lobbying firms or interest groups (i.e. public affairs know-how).

The formalized, or "structured" CPA that prevails in rule-governed systems does not exist in relationship-based systems (Lawton et al., 2013a: 92). Here, the public affairs culture is missing (Harsányi and Schmidt, 2012) and CPA remains a taboo (Sallai, 2013). Instead, CPA is mainly limited to informal personal contacts between politicians, public officials, and managers. Informal network- and relationship-based types of CPA matter in developed countries too (King and Pearce 2010; McDonnell and Werner 2016); but they tend to be less important, more transparent, and less particularistic than in developing ones (Peng 2003; Sun et al., 2015).

As such, the institutional context may make certain CPA types ineffective. Indeed, the political capabilities that Western researchers consider associated with political strategies such as "the introduction of incentive systems that accelerate the speed and quality with which public policy demands are implemented" (Oliver and Holzinger, 2008: 508), may be 
utterly inadequate to deal with volatile relationship-based environments (Darendeli and Hill, 2016; Oh and Oetzel, 2017). In particular, radically changing political environments - e.g. due to wars and rebellions - dramatically change the effectiveness of certain political resources and require specific political strategies based on locally-developed political capabilities for firms to survive (Darendeli and Hill, 2016; Getz and Oetzel, 2009; Oetzel and Oh, 2014; Oh and Oetzel, 2017). In such situations, even political ties may be unreliable political resources and more sophisticated, locally-adapted CPA may be required (Darendeli and Hill, 2016; White et al., 2018).

Conversely, relationship-based strategies and the related resources and capabilities, may lose their legitimacy, effectiveness, and hence value when the institutional environment moves from a relationship-based towards a rule-based or arm's length system (Sun et al., 2010). Certain types of CPA may simply not be considered legitimate in certain environments and may hence be counterproductive (Darendeli and Hill, 2016; Sallai, 2013). This goes beyond the question of whether the company engaging in CPA is perceived as an outsider and hence considered illegitimate (Hillman \& Wan, 2005), but concerns the very nature of the capabilities themselves that firms - outsider or not - mobilize.

From the "fit perspective," this hints at a tension facing subsidiaries of Western MNEs active in environments characterized by volatility and in particular "institutional backsliding": while they need to strive for "organizational fit" of their political strategies with their home country institutionally-shaped capabilities, the latter may become increasingly ineffective in dealing with a host country institutional environment that moves away from formal institutions and becomes less predictable. Conversely, those that are most effective at achieving "institutional fit" in the host context, are the least suitable to achieve “organizational fit," e.g. because particularistic personal political capabilities are less legitimate in the home environment. Moreover, the capabilities needed to deal with the 
volatile environment may not be readily available to subsidiaries, as they are strongly locallyembedded and may take a long time for firms to develop (Carney et al., 2016; Darendeli and Hill, 2016), while the capability to quickly mobilize political resources constitutes a crucial dynamic capability for firms to cope with volatile environments (Oliver and Holzinger, 2008). We call this the "transferability-value dilemma" - whereby the most readily available capabilities through transfer are the least valuable in the volatile context, while the most valuable ones are both more difficult for subsidiaries to acquire and reduce "organizational fit." In the next section, we argue that the resolution to will depend on the transferability of different types of political capabilities.

\subsection{The transferability of political capabilities}

The "fit paradigm" as applied to the CPA literature is implicitly based on a strong assumption regarding the transfer of capabilities and practices from headquarters to subsidiaries. Indeed, "organizational fit" essentially implies that subsidiaries develop strategies that use the same capabilities as the parent company, which in turn necessitates transference.

The MNE's ability to leverage intangible knowledge resources and reconfigure assets across national borders constitutes possibly its most important dynamic capability (Dunning and Lundan, 2010; Jensen and Szulanski, 2004). This also applies to CPA: MNEs can transfer political capabilities developed in the home country (Carney et al., 2016; Holbourn and Zelner, 2010) or in other host countries (Delios and Henisz, 2003) to a new host environment. Carney et al. (2016) show that certain capabilities to deal with authoritarian governments can be transferred across similar institutional environments. Similarly, White et al.'s (2018: 13) implicitly consider intra-MNE transference of non-market practices through "people, processes, resources" to be straightforward.

Transference of political capabilities may reduce the time an organization needs to adapt to a new political environment, because transfer of existing capabilities can be expected 
to be quicker than locally developing new ones and may hence constitute a key capacity to develop effective political strategies in volatile environments (Oliver and Holzinger, 2008).

Yet, the literature on transfer of practices (Edwards et al., 1999; Edwards et al., 2015; Ferner et al., 2012; Gamble, 2010; Kostova, 1999; Kostova et al., 2008) and in particular on the "stickiness" of practices and capabilities (Szulanski, 1996; Jensen \& Szulanski, 2004) has shown that leveraging capabilities across borders is far from a straightforward process. Not all political capabilities may be transferable across borders (Bonardi et al., 2006; Doh et al., 2012; Oh and Oetzel, 2017). Yet, the determinants of transferability of political capabilities have not systematically been studied. Here we draw on the practice transfer literature to cover this gap.

The transfer literature considers that a key factor affecting political capabilities' transferability or "stickiness" is the ability to codify the underlying knowledge. Thus, Dunning and Lundan (2010: 1227) consider that "transfer requires that specific practices can be isolated and articulated into routines that can become 'best practices'." If a capability is codifiable, "knowledge-based conduits" of transfer, such as specialist information systems, can be put in place to facilitate transfer within the MNE (Edwards et al., 2015).

Yet, by far not all political capabilities are codifiable. Indeed, many of them are related to informal practices that are based on very personal and tacit knowledge. Thus, in general, Hillman and Wan (2005: 328) argue that the financial incentive political strategy can be more easily transferred across borders than the information- and constituency-building strategies, because the former are based on tangible assets (such as money) while the latter rely on relational "political skills." Oh and Oetzel (2017) find that the capability acquired by an MNE subsidiary to manage violent conflict may be too country-specific to be valuable in another host country (Oh and Oetzel, 2017). They argue that discontinuous risks, i.e. "those that are episodic and difficult to anticipate" (Oh and Oetzel, 2017: 727) may require more in- 
depth, context-specific knowledge, which can be expected to make them less valuable in other contexts (also Oh and Oetzel, 2011; Perkins, 2014). Conversely, "continuous risks"e.g. corruption and policy uncertainty - may be less country-specific and capabilities developed to deal with such risks in one country can be expected to be valuable to deal with similar risks in other countries (Oh and Oetzel, 2017: 727, Perkins, 2014).

Capabilities that cannot easily be codified, may still be transferable to some extent, notably through "people-based conduits" for transfer of tacit knowledge, e.g. expats (Edwards et al., 2015). Yet, here the specificity of political capabilities is important: while production or sales related capabilities (Luo \& Park, 2001), as well as capabilities related to internal functions such as HRM (Edwards et al., 2015) may involve employees at different levels, the nature of political strategies is such that they often concern the higher-echelons of the corporate hierarchy. This limits their transferability through people-based conduits, as the pool of holders of the required tacit knowledge is narrower in this area.

We now turn to revisiting existing typologies of political capabilities to enhance them with the dimensions of stickiness/transferability.

\subsection{Typologies of political capabilities - old and new}

Different typologies of political strategies exist, which assume different types of resources and capabilities underlying each strategy. Hillman and Hitt (1999: 825) distinguish information-, financial incentive-, and constituency-building- strategies. The informational strategy is associated with formal lobbying or commissioning and delivering technical reports (Hillman and Hitt, 1999: Table 1). The financial incentive strategy is associated with contributions to politicians and parties, while the constituency building strategy relies on grassroot mobilization of employees, suppliers, or customers.

Oliver and Holzinger's (2008) suggest another typology based on the distinction between a "compliance approach" and an "influence approach" to CPA. The former focuses 
on a firm's internal capabilities and aims at adapting the organisation to its political environment by reacting to regulatory changes (the reactive strategy) or anticipating such changes (the anticipatory strategy). The influence approach, on the other hand, uses a firms' external capabilities and aims at shaping the institutional environment by trying to protect the status quo from unwanted political change (the defensive strategy), or by actively promoting institutional change that benefits the firm (the pro-active strategy) (Oliver and Holzinger, 2008: 507). Internal capabilities include organizational routines that insure compliance with laws and allow firms to anticipate policy change with a view to gain a first mover advantage by complying early (Oliver and Holzinger, 2008: 509). External capabilities include the deployment of social capital stemming from ties with policy-makers and lobbying to prevent changes that would undermine the company's competitive advantage (Oliver and Hozlinger, 2008: 510).

These two classical typologies of political capabilities have two important shortcomings when applied to MNE CPA in emerging markets. Namely, they neglect the institutional structuring and fit of political capabilities (Whitley, 2007) and their transferability across borders (Carney et al., 2016).

Regarding institutional structuring, Hillman and Hitt's (1999) suggest that the three strategies and related capabilities can be deployed across a variety of contexts. Indeed, which strategy to choose is mainly a firm-level decision, while institutional factors are only a secondary determinant. The only institutional determinant in their framework is the degree of pluralism/corporatism that prevails in a country: In corporatist countries firms are more likely to choose a relational approach to $\mathrm{CPA}$; attempting to establish relationships with policy makers to influence the political environment pro-actively and on an ongoing basis, often using collective action by business associations rather than individual action. In pluralist countries, a transactional CPA approach where firms deal with political and legislative issues 
on an ad hoc basis when they arise is more likely (Hillman and Hitt, 1999: 828ff). Yet, the distinction between pluralist and corporatist settings may be important in Western countries, but cannot account for the much more strongly locally-embedded political capabilities that exist in non-Western settings (Carney et al., 2016; Oh \& Oetzel, 2017; Darendeli \& Hill, 2016). Furthermore, the nature and degree of local embeddedness, will also affect the transferability of capabilities, which existing typologies neglect. We propose a new typology of political capabilities that takes into account their transferability and is summarized in table 1. 
Table 1: Transferability and Formality/Codification of political capabilities

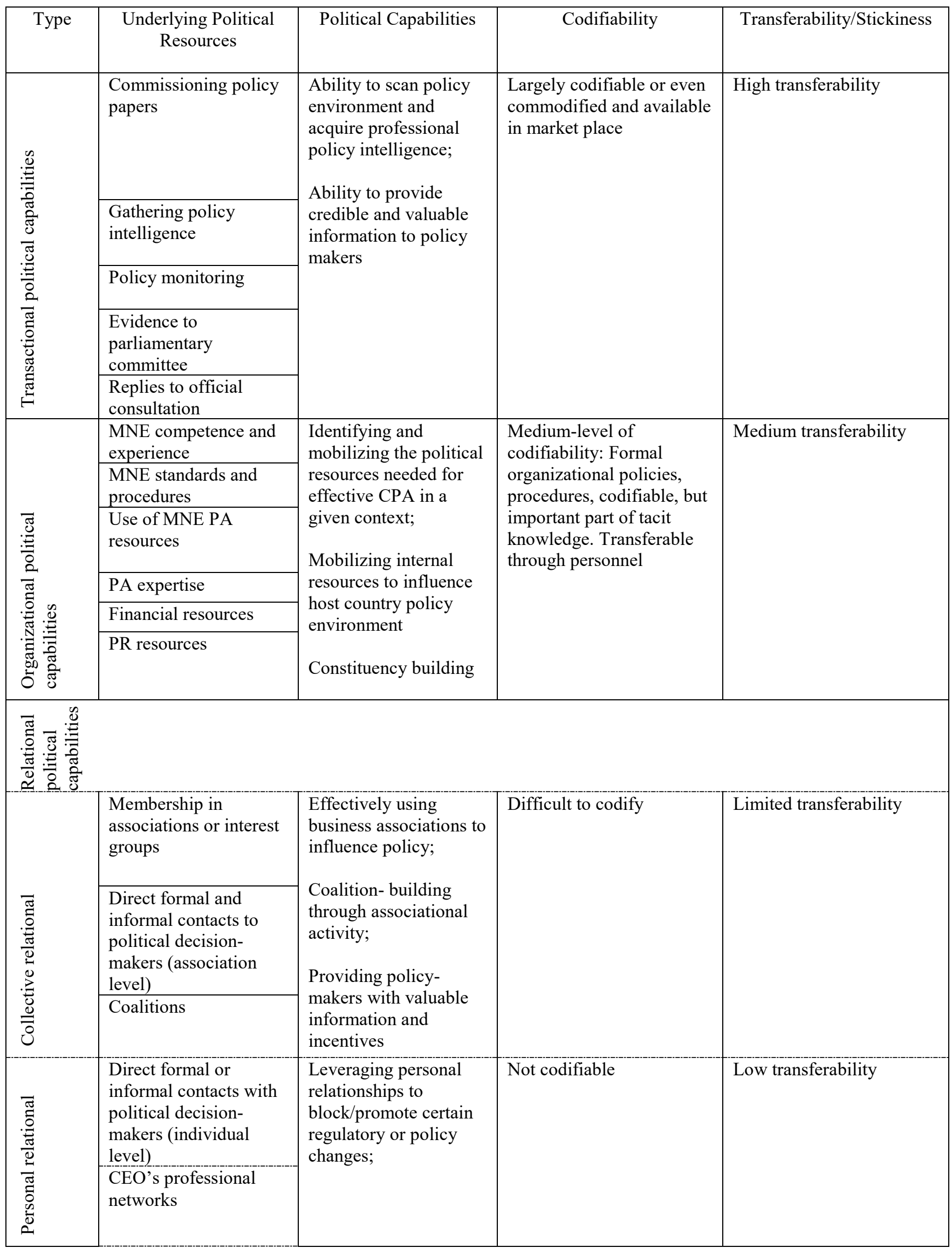




\begin{tabular}{|l|l|l|l|}
\hline & $\begin{array}{l}\text { Provision of valuable } \\
\text { information or } \\
\text { incentives }\end{array}$ & & \\
\hline
\end{tabular}

Like existing typologies (Lawton et al., 2013a; Oliver and Holzinger, 2008), we distinguish internal- or 'organizational' from external political capabilities. Organizational political capabilities are those that are readily available within the organization (e.g. internal expertise) (Jensen and Szulanski 2004). They draw on organizational resources such as internal policy analysis, public affairs departments etc. While organizational capabilities may be codified (e.g. through internal regulations and formal policies - Teece et al., 1997), they may also be based on tacit, non-codifiable knowledge. Organizational capabilities are by definition, contingent on the organizational institutional environment in the sense that organizations will develop them in reaction to the institutional environment in which they originate (Child et al., 2012). Therefore, we would expect organizational capabilities of DMNEs and their subsidiaries to differ from DFs from relationship-based systems.

We further distinguish two types of external capabilities, namely capabilities deployed based on market transactions, which we call transactional capabilities, and capabilities deployed via social networks, which we call relational capabilities. Capabilities in the transactional category broadly correspond with capabilities required for what Hillman and Hitt (1999) call the transactional CPA approach and include capabilities linked to ‘information strategy', such as formal lobbying (Hillman and Hitt 1999). They are characterized by their reliance on formal market exchanges based on codified knowledgeassets. Thus, official exchange of expertise and information e.g. through formal channels such as responses to consultation procedures, fall into this category. Similarly, formal lobbying efforts such as a company's ability to acquire political intelligence from a third party - e.g. a policy research or consultancy firm - would also qualify as a transactional political capability. Generally, transactional political capabilities - like other market-based (intangible) assets 
(Barnard, 2010) - can be acquired in the market place, and tend to be codifiable and commodifiable, which decreases their stickiness. As such, they are related to tangible resources - including financial ones - used by firms in the financial political strategy as described by Hillman and Wan (2005).

In contrast, relational capabilities, which correspond with capabilities used in Hillman and Hitt's (1999) relational approach to CPA, include formal and informal contacts and ties with political decision-makers that are based on non-codified and often implicit knowledge. Following Zhang et al. (2016), who distinguish collective CPA from personal ones, we further distinguish relational political capabilities according to whether they exist at the individual level or at the collective level of the organization. Thus, memberships in industry associations or interest groups are collective relational political resources, while a CEO's personal network is classified as an personal political resource (cf. Zhang et al. 2016). In practice, the difference may not always be clear-cut. Thus, formal and informal meetings with public officials can be classified either as a collective capability (e.g. managers as representatives of the company meeting with public officials) or a personal one (a top manager meeting with public officials based on friendship-, family-, or other personal ties). However, the two can be analytically distinguished, based on the motivation for action; namely personal loyalty/friendship or organizational objectives.

Transferable capabilities exist in all three categories e.g. money is an easilytransferable organizational capability, membership in a business association an easily transferable collective relational one (cf. Bonardi, 2011). However, we would still expect the first two categories in this typology to be more readily transferable than capabilities of the relational type, because relational ones are usually mainly based on tacit knowledge in the form of personal relational skills and hence not codifiable (Hillman \& Wan, 2005). We would also expect collective relational capabilities to have some degree of transferability, while 
personal relational ones have the lowest transferability, because they are tied to specific individuals rather than being impersonal like organizational relationships. Therefore, they can only be transferred through upper-echelon personal conduits (cf. Edwards et al., 2015).

The question of transferability of different types of capabilities has implications for the question of their value, to which we now turn.

\subsection{Value and institutional fit of political capabilities}

The value of a political capability can be defined in two ways: firstly, its availability to the firm and secondly its usefulness in dealing with the institutional environment - i.e. its “institutional fit."

Regarding availability, the political capabilities literature generally follows the "resource-based view" in considering that the resources a political strategy generates are "valuable, inimitable, and imperfectly mobile across firms" (Oliver and Holzinger, 2008: 512). Tacit knowledge reduces the imitability and hence transferability of routines across firms and thus increase their value (Kotabe et al., 2011). Yet, transferability of political resources and capabilities within firms may be key to MNC competitiveness in fast changing environments by making important capabilities available. Here codifiability and hence imitability, which increases intra-MNE transferability, may increase rather than decrease the value of a political capability to a given firm. Indeed, Bonardi (2011) argues that the key RBV tenant of inimitability of resources has only limited relevance for the value of political capabilities. Thus, the most important political resource - money spent on lobbying and campaign contributions - is not hard to imitate (Bonardi, 2011: 248). The same is true, to an extent, for membership in business associations; another widely-used - and hence evidently valuable - political resource (Bonardi, 2011). In terms of the "fit paradigm" transferable political capabilities are valuable, because they allow it to achieve "organizational fit." 
Yet, while transferability may positively affect political capabilities in terms of availability, it may have a contrary effect on the second determinant of political capability value, namely “institutional fit." Thus, Oh and Oetzel (2017) find that knowledge-assets transferred through the MNE tend to be more superficial and less adapted to the local context than locally-developed ones. Here our typology suggests a different way in which the value of political capabilities is determined, namely through their "institutional fit" with the environment. The more rule-governed a system is, the more transactional political capabilities will be effective and hence valuable, because market-based political resources are available and market-based CPA is legitimate (Lawton et al., 2013a). Conversely, the more relationship-based it is, the more personal and organizational political ties can be expected to be important for effective CPA (Boddewyn, 2016; Sun et al., 2010). Within relationshipbased systems, the more discontinuous political risks there are, the more context-specific political capabilities will have to be to be effective (Oh \& Oetzel, 2017). Since personal relational political capabilities are the most context-specific, they are hence most legitimate and valuable in achieving "institutional fit" in such situations.

Organizational political capabilities are less easy to classify in terms of "institutional fit," because they have by definition co-evolved with the institutional environment. Indeed, a company's experience will lead it to develop specific capabilities, which are adapted to the local environment (Oh and Oetzel, 2017). Therefore, their fit with the dichotomy of relationship- vs. rules-based institutional environments is contingent on the company's history and previous experience. For MNEs from rule-governed systems, however, the organizational political capabilities can be expected to be potentially valuable in both types of environments, because they have been developed in reaction to a transaction-based environment and are hence in general more versatile than relational ones (Hillman \& Wan, 2005). 
We expect the interaction between transferability and institutional fit to determine the effectiveness of MNE subsidiary CPA. The more relationship-based a system (especially when risk is discontinuous), the more transferable transactional capabilities lose value and the stickier relational ones become important, the nature of organizational capabilities in developing locally relational ones may hence determine the effectiveness of the subsidiary's political strategy (cf Table 2).

Table 2: Institutional fit and value of political capabilities in a host-country setting

\begin{tabular}{|c|c|c|c|}
\hline $\begin{array}{c}\text { Political } \\
\text { capabilities }\end{array}$ & Rule-based & $\begin{array}{l}\text { Relationship-based (continuous } \\
\text { risk) }\end{array}$ & $\begin{array}{l}\text { Relationship-based } \\
\text { (discontinuous risk) }\end{array}$ \\
\hline 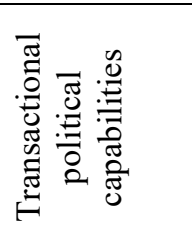 & $\begin{array}{l}\text { Legitimate and valuable } \\
\text { and }\end{array}$ & Less legitimate and less valuable & Worthless \\
\hline 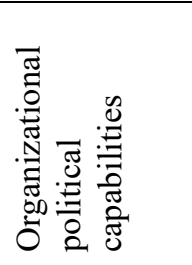 & $\begin{array}{l}\text { Potentially valuable, but } \\
\text { contingent on past } \\
\text { experiences }\end{array}$ & $\begin{array}{l}\text { Potentially valuable, but contingent } \\
\text { on past experiences }\end{array}$ & $\begin{array}{l}\text { Potentially } \\
\text { valuable, but highly } \\
\text { contingent on past } \\
\text { experiences }\end{array}$ \\
\hline 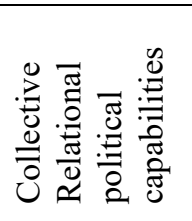 & Valuable and legitimate & Crucial & $\begin{array}{l}\text { Less legitimate and } \\
\text { less valuable }\end{array}$ \\
\hline 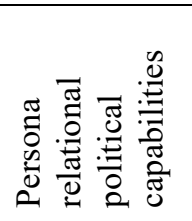 & $\begin{array}{l}\text { Less legitimate, but } \\
\text { potentially valuable }\end{array}$ & Crucial & Crucial \\
\hline
\end{tabular}

In our empirical study, we apply this framework to develop propositions regarding the competitive advantage implications of the transferability of political capabilities.

\section{Methods}

\subsection{Empirical context: Institutional backsliding in a post-socialist country}


To explore how Western subsidiaries adapt their CPA to an increasingly volatile political environment, we focus on the case of Hungary in a period of radical institutional change. We focus on MNEs from developed countries and assume that they all share a fundamentally rule-governed home environment, while Hungary as host environment has increasingly moved from a relatively rule-governed to a relationship-based one, and risk has increasingly become discontinuous.

Since the start of its post-socialist transition in the 1990s, Hungary has been an important case for scholars (Martin, 2013; Stark and Bruszt, 1998; Whitley et al., 1996). By the mid-2000s, it had advanced to one of the most consolidated democracies among postsocialist countries (EBRD, 2005). Since the 2010 elections, - when Viktor Orbán's conservative party Fidesz acquired a two-thirds majority in the parliament - however, Hungary's "democracy score" has declined, bringing it closer to some of the less developed semi-consolidated democracies, like Romania and Bulgaria (Walker and HabdankKołaczkowska, 2012: 6). This recent trend that has been observed in several post-socialist countries has been termed 'backsliding,' which describes the move from the initial promarket reform path towards a more authoritarian political system and a more state-controlled economy (Greskovits, 2015; Sedelmeier, 2014).

\subsection{Case selection and research design}

Our study is based on a longitudinal case study, which is suitable to investigate the temporal and processual nature of the phenomenon under investigation, namely the development of political strategies using transferred political capabilities (cf. Carney et al., 2016).

Hungary as a case of continuing post-socialist transition (Meyer and Peng, 2016) that experienced an important 'external shock' in the form of the authoritarian Fidesz government of Viktor Orbán acquiring a two-thirds parliamentary majority in 2010, which allowed him to 
fundamentally change the political system, culminating in the March 2013 constitutional amendment. This shock led to a phase of 'backsliding' (Greskovits, 2015), which is synomnymous with institutional uhpeaval and discontinuous political risk. Hungary therefore constitutes a natural experiment that can shed light on the transfer of political capabilities to deal with volatile political contexts. Natural experiments can "offer insights into the causal relations between variables and so can provide a firm foundation for theory development" by illuminating and extending theory (Darendeli and Hill, 2016: 6). We use a multiple-group before-after design in the sense that we compare the strategies to deal with the Orbán government's increasingly authoritarian and unpredictable nature across a group of Western MNEs and domestic Hungarian firms.

\subsubsection{Sample}

Our first group is constituted of Western MNEs. Our sample is based on purposive sampling through predetermined selection criteria, as it is often the case in qualitative research (Miles and Huberman, 1994). Ideally, the sample should be constituted in a way that holds as many variables as possible constant (Darendeli and Hill, 2016). Yet, due to the small size of the Hungarian economy and the sensitive nature of the topic at hand, which led to a low willingness of firms to participate in the study, our MNE sample comes from different home countries and different industries. Nevertheless, they form a single group in terms of the spatial and institutional proximity of the home countries, which are all highly developed western countries. This choice is justified by our interest in the ability of MNEs from rulegoverned countries to transfer political capabilities to relationship-based systems. The second group are domestic Hungarian firms also distributed across a variety of sectors. The Hungarian firms constitute a control group in the sense that it is composed of domestic firms, which do not have the possibility of transferring capabilities. 
While a self-selection bias cannot be completely excluded, we are confident that our results are not affected by this shortcoming. Indeed, the sectoral composition of the sample is diverse: Overall, our sample contains firms from eleven different industries. The largest industries in our sample were ICT and the construction sector.

\subsubsection{Treatment}

The treatment is the amendment in March 2013 of the constitution that the Fidesz government had enacted only in 2012. While the Fidesz government had a super-majority in parliament since the 2010 election, the process of 'backsliding' started after the power of the Supreme Court had been curtailed and the government thus obtained nearly unlimited legislative power with the constitutional change in 2013. Indeed, in 2014, PM Orbán declared Hungary to have become an "illiberal state" (Magyar, 2016: 62). Our data collection started in 2011 and ends in 2017. The period of 2011-3 constitute our 'before' period, because the institutional system during this period was still relatively stable compared to the institutional upheaval following the 2013 constitutional amendments, although the Orbán government was already in control. Moreover, our first interviews often related to companies' experience with the pre-2010 institutional environment.

\subsection{Data collection and analysis}

Our data stem from multiple rounds of data collection and a variety of sources: indepth interviews with business leaders and experts from the context of the case, as well as documentary analysis of news and various reports over seven years. Data collection and data analysis was carried out in parallel. We went back and forth in an iterative process to interpret our material and reflect on how it advanced our understanding of the constructs used in the literature. Overlaps in data collection and analysis are beneficial, since it speeds up the analysis and "reveals helpful adjustments to data collection" (Eisenhardt, 1989: 535). 
To obtain multiple perspectives and a more complete and nuanced view of firms' political capabilities, we sought a range of opinions as recommended for this type of research (Perry, 1998: 798). We carried out 56 semi-structured interviews (see table 3): 43 with business leaders working at MNE subsidiaries and domestic firms and a further 13 with experts in the context of the case. The MNE subsidiaries in the sample originated from the US (6), France (4), Germany (3), United Kingdom (1), Switzerland (1), Denmark (1), Italy (1), and the Netherlands (1). We tended to interview only one person per company, because political activity in Hungary is virtually always limited to the very top of the managerial hierarchy (Sallai, 2013). Therefore, in most cases the CEO, the Managing Director or the public affairs director were deemed to possess the necessary information to answer our questions. Due to the longitudinal nature of the study, we have interviewed in several cases the same respondents both in the early years of the Orbán regime in 2011-2013 as well as recently in 2015-17. We carried out 32 interviews in the first period (2011-2013) and another 24 in the second (20152017). This allowed us to obtain informed views on the changes over time.

Table 3: Number of interviews per sector, title of interviewee and date

\begin{tabular}{|c|c|c|}
\hline Company industry (number of interviews) & Position of interviewee & Date of interview \\
\hline \multirow{6}{*}{ 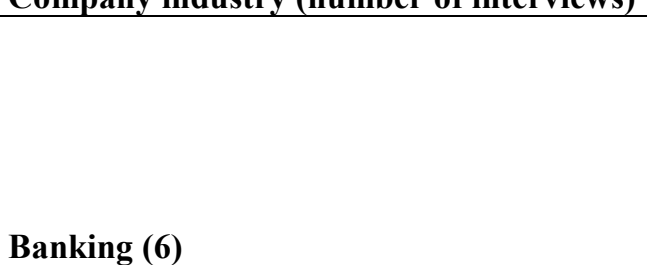 } & CEO (Subsidiary) & 15.07 .2016 \\
\hline & CEO (Local) & 13.07 .2016 \\
\hline & CEO (Subsidiary) & 24.01 .2012 \\
\hline & Vice-CEO (Local) & 07.03 .2012 \\
\hline & CEO (Subsidiary) & 26.01 .2012 \\
\hline & Vice-CEO (Subsidiary) & 07.03 .2012 \\
\hline \multirow[b]{7}{*}{ Construction (7) } & Director (Local) & 15.07 .2016 \\
\hline & CEO (Subsidiary) & 10.04 .2015 \\
\hline & CEO (Subsidiary) & 11.01 .2012 \\
\hline & CEO (Local) & 07.03 .2012 \\
\hline & CEO (Local) & 15.11 .2011 \\
\hline & Director (Local) & 20.06 .2011 \\
\hline & CEO (Local) & 22.06 .2011 \\
\hline \multirow[b]{6}{*}{ Energy (6) } & PA Director (Subsidiary) & 10.04 .2015 \\
\hline & PA Director (Subsidiary) & 06.05 .2013 \\
\hline & Director (Local) & 04.08 .2011 \\
\hline & Head of Strategy (Local) & 02.07 .2011 \\
\hline & PA Director (Subsidiary) & 06.09 .2011 \\
\hline & Director (Local) & 31.08 .2011 \\
\hline
\end{tabular}




\begin{tabular}{|c|c|c|}
\hline \multirow[b]{7}{*}{ ICT (7) } & CEO (Local) & 12.04 .2017 \\
\hline & Director (Subsidiary) & 16.02.2017 \\
\hline & CEO (Local) & 16.07.2016 \\
\hline & $\begin{array}{l}\text { Director of Government Affairs } \\
\text { (Subsidiary) }\end{array}$ & 26.01.2012 \\
\hline & Former CEO (Subsidiary) & 05.09 .2011 \\
\hline & CEO (Local) & 16.06 .2011 \\
\hline & $\begin{array}{l}\text { Former Director of Government } \\
\text { Affairs (Subsidiary) }\end{array}$ & 01.09 .2011 \\
\hline \multirow[b]{5}{*}{ Manufacturing (5) } & Director (Subsidiary) & 31.05 .2017 \\
\hline & CEO (Subsidiary) & 23.08 .2016 \\
\hline & CEO (Subsidiary) & 23.08 .2016 \\
\hline & CEO (Local) & 15.12 .2011 \\
\hline & CEO (Local) & 20.06 .2011 \\
\hline \multirow[b]{2}{*}{ Telecommunication (2) } & CEO (Subsidiary) & 15.08 .2016 \\
\hline & Vice-CEO (Subsidiary) & 09.08 .2015 \\
\hline \multirow[b]{4}{*}{ Retail (4) } & Director (Subsidiary) & 15.07.2016 \\
\hline & Director (Subsidiary) & 13.08 .2016 \\
\hline & Director (Subsidiary) & 16.04 .2012 \\
\hline & $\begin{array}{l}\text { General Managing Director } \\
\text { (Local) }\end{array}$ & 08.05 .2011 \\
\hline \multirow[b]{2}{*}{ Wholesale (2) } & CEO (Local) & 13.02 .2017 \\
\hline & CEO (Local) & 30.03 .2012 \\
\hline \multirow{4}{*}{$\begin{array}{l}\text { All other sectors: tobacco, tourism, advertising, } \\
\text { beverages }(4)\end{array}$} & Director (Subsidiary) & 16.02 .2017 \\
\hline & Managing Director (Subsidiary) & 16.08 .2016 \\
\hline & Managing Director (Local) & 16.02 .2013 \\
\hline & CEO (Local) & 30.03 .2012 \\
\hline \multirow[b]{13}{*}{ Experts from the context of the case (13) } & Secretary General & 17.02 .2017 \\
\hline & \begin{tabular}{|l|} 
Managing Director \\
\end{tabular} & 13.04 .2017 \\
\hline & Secretary General & 29.05 .2017 \\
\hline & Secretary General & 16.08 .2016 \\
\hline & Public affair Director & 13.08 .2016 \\
\hline & Managing Director & 23.01 .2012 \\
\hline & Secretary General & 11.01 .2012 \\
\hline & Managing Director & 22.11 .2011 \\
\hline & Executive Director & 16.11 .2011 \\
\hline & Director & 09.11 .2011 \\
\hline & Managing Director & 28.09 .2011 \\
\hline & Journalist & 31.05 .2017 \\
\hline & Political adviser & 31.08 .2011 \\
\hline Total number of interviews (56) & $\begin{array}{l}2011(18), 2012(12), 2013(2), \\
2015(3), 2016(12), 2017(9)\end{array}$ & 56 \\
\hline \multirow[b]{2}{*}{ Total number of interviews at firms (43) } & MNE subsidiaries & 23 \\
\hline & Domestic firms & 20 \\
\hline
\end{tabular}

In-depth interviews are an insightful method for exploring the "often nuanced causal factors of specific managerial action" (Lawton et al., 2013b: 231). By allowing comparison (Flynn et al., 1990), the semi-structured interview technique provided a single framework for 
the different interviews but also gave flexibility to ask questions in relation to previously not identified issues that arose from the interviewee's responses (Bryman, 2004).

Interviews were conducted in English and in Hungarian. Interviews in Hungarian were translated by one of the authors. Interviews were conducted and recorded by one of the researchers at the respondents' offices and were later transcribed. Each interview lasted for 5090 minutes. Most interviews were carried out in Budapest.

In addition to the interviews, we used secondary sources to increase our confidence about the reliability of the interview responses. We analyzed over 70 pieces of printed and online newspaper articles and reports from corporate websites, journalistic sources, and publications by reputable NGOs such as Transparency International. Due to the lack of scholarly research on these topics in Hungary, such sources are often the only information available and are more reliable than official government sources.

After the transcription of the interviews we used the NVivo software to perform an open coding of the data according to recurring themes. This first step was followed by and compared to a process of axial coding. We used both open and axial coding, because we seek to "refine and differentiate concepts that are already available" (Böhm, 2004: 271). Indeed, we used the theoretical concepts of stickiness, transferability, value, transactional-, organizational-, and (personal and collective) relational political capabilities as our categories. In the post-coding stage, we followed Miles and Huberman's (1994) framework - namely the process of reducing data, displaying data, and drawing and verifying conclusions.

The goal of the analytical process was to determine whether the different political capabilities fall into the categories of "sticky" or transferable. We looked for evidence indicating the stickiness and transferability of different capabilities and how they are acquired or developed by different firms. Next, we selected the most relevant quotes that would illustrate the different capabilities of each firm type. We then used our other data to better 
understand how these capabilities were developed and used and whether these capabilities were transferable or not (explanation building).

In the last step of data analysis, we used our data to understand how the value of different political capabilities has changed as a result of the changes in the institutional environment and how the availability of capabilities changed as a consequence.

During the second round of interviews, we started to refine emerging themes and asked respondents to comment directly on specific aspects of our emerging findings. The use of this type of external check mitigated the potential biases of individual respondents and enabled us to induce richer insights from the aggregate data (Santos and Eisenhardt, 2009).

Throughout the overlapping data collection and analysis, we sought to critically engage with the interview data and situate them within the broader context of informants' interests and social position. Through this process of triangulation and iteration, we sought to decrease possible bias and interpret the data in a more nuanced manner (Yin, 2003).

\section{Findings}

Our empirical case allows us to explore how foreign subsidiaries seek to develop effective CPA strategies to cope with radically changing institutional environments, while achieving both "organizational-" "institutional fit." We present our findings distinguishing three phases, the transition period from 1989 to 2010 when formal structures of interest representation became more important in Hungary and the institutional system more generally shifted towards a Western-style rule-governed environment - especially in preparation for EU-membership (EBRD, 2005). This process was halted when Orbán's Fidesz party obtained a two-thirds majority in the 2010 election, which marks a change in direction of institutional reform that we call "backsliding." While relatively slow and tentative at first, backsliding accelerated after the adoption of the new constitution in 2014, which is why we consider the years since 2014 as a new phase, characterized by high levels of unpredictability and discontinuous political risk. 
Before Orbán's accession to power and in the early phase of his government, our interviews show that while subsidiaries relied on all three types of capabilities (transferable transactional and organizational ones, as well as stickier relational ones), DFs predominantly relied on relational capabilities. Indeed, MNEs were able to leverage transferred transactional and organizational capabilities to engage with the formal policy-making process, even during the early Orbán years when the government started to make these formal channels more difficult. Virtually all respondents stressed the difference in the availability of transactional and organizational capabilities for MNEs and their absence in DFs, which meant DFs were largely excluded from the formal policy-making process. One respondent stated:

"When the government - reluctantly - sends documents for review or debate, it tries to prevent opinions by sending the document last night, requiring feedback by the following morning. Companies are normally not prepared to submit any feedback to these. But multinationals are prepared to give feedback even in 24 hours." (Respondent, Subsidiary11)

Top managers of subsidiaries want to know who is dealing with a given policy in the different ministries, because transferable organizational capabilities allow them to prepare analysisbased lobbying documents that can be channeled into the legislative process early on (Respondent, Subsidiary11). Some DFs too undertake certain types of transactional political strategies - e.g. systematic legislative monitoring (e.g. Respondent, Local 16). However, these strategies appear less effective than MNE subsidiaries' activities due to the relative lack of organizational resources compared to subsidiaries (e.g. Respondent, Local 9; Respondent, Local 8). One respondent stated:

"Hungarian lobbying is more a surface type lobbying, not carrying hundreds of pages of professional arguments” (Respondent, Local 5). 
It becomes hence clear that during the pre-Orbán and early-Orbán phase, MNE subsidiaries achieved a comparative advantage by transferring transactional and organizational political capabilities from the home country. These capabilities both achieved "organizational fit" and "institutional fit" with an increasingly rule-based environment. Yet, even then, the institutional context in Hungary was still more relationship-based than the Western MNEs' home context. This implied that to achieve "institutional fit" relational political capabilities were important for MNEs too. Our interviews show that when entering the country, subsidiaries were at a certain disadvantage compared to domestic firms, because they lacked local relational resources to deal with the relational host context and these relational capabilities could not be easily transferred from the home environment (e.g. Respondent, Subsidiary 14). Local firms, on the other hand, were often well-connected to the state bureaucracy. As the respondent from one local firm simply put it: "[We] have to have good contacts with the state. We know everybody" (Respondent, Local 10; similarly, respondent Local6).

However, MNEs managed to overcome this disadvantage by locally developing relational political capabilities. Interestingly, however, they did so by leveraging their transactional and organizational political capabilities. One important way in which MNE subsidiaries developed collective relational capabilities is by hiring well-connected local staff - effectively using the MNE's organizational capability to pay good salaries to attract wellconnected individuals. Thus, interviewees at local subsidiaries stated:

"The best is to employ somebody, or a company who have done this [political activity] already in this country." (Respondent, Subsidiary10)

“...we employed more Hungarian managers to develop business relationships but also political relationships". (Respondent, Subsidiary4)

More generally, the CEO plays a much more important role in managing political activities and is often involved in direct political negotiations with policy-makers. Previous 
studies have shown the importance of top-level political networks for successful CPA in Hungary (Sallai, 2013). The CEO represents a subsidiary-related resource that is integrated into the local political strategy through personal relational capabilities.

In short, during the first two phases foreign subsidiaries were able to develop successful political strategies by leveraging transactional and organizational political capabilities in an increasingly rule-governed environment, while local firms had not developed transactional and organizational capabilities to deal with such an environment. This suggests that the transfer of transactional and organizational political capabilities and leveraging them to locally develop relational ones allowed subsidiaries to achieve "organizational-" as well as "institutional fit" and provide them with an advantage compared to DFs. Table 4 summarizes the key findings regarding the availability of different types of political capabilities to MNEs and DFs and provides representative quotes from the interviews.

Table 4: Availability of political capabilities to subsidiaries and domestic firms

\begin{tabular}{|c|c|c|c|}
\hline & & \multicolumn{2}{|c|}{ Representative Quotes } \\
\hline Type of capability & Examples & MNEs & Domestic Firms \\
\hline $\begin{array}{l}\text { Transactional } \\
\text { capabilities }\end{array}$ & $\begin{array}{l}\text { Political strategy } \\
\text { Policy papers } \\
\text { Coalition building } \\
\text { Intelligence } \\
\text { Policy monitoring } \\
\text { Policy replies }\end{array}$ & $\begin{array}{l}\text { "Hungarian companies do it [lobbying] } \\
\text { on their own, or they go through an } \\
\text { association and plus they engage in } \\
\text { their own ways as well, by finessing... } \\
\text { At [multinationals,] it [lobbying] is } \\
\text { coordinated. And in the associations } \\
\text { our professionals prepare very serious } \\
\text { documents and all the lobbyists of the } \\
\text { industry say the same. We argue for } \\
\text { industrial interests." (Respondent, } \\
\text { Subsidiary11) }\end{array}$ & $\begin{array}{l}\text { "Our interest representation was } \\
\text { not very effective before either, } \\
\text { but today even less. There is } \\
\text { [only] the media and our } \\
\text { [informal] discussions with the } \\
\text { decision-makers." (Respondent, } \\
\text { Local 09) }\end{array}$ \\
\hline $\begin{array}{l}\text { Organizational } \\
\text { capabilities }\end{array}$ & $\begin{array}{l}\text { MNE competence } \\
\text { and experience } \\
\text { MNE standards and } \\
\text { procedures } \\
\text { Use of of MNE PA } \\
\text { resources } \\
\text { PA expertise }\end{array}$ & $\begin{array}{l}\text { "There is huge experience and } \\
\text { background internally at these } \\
\text { companies [MNE subsidiaries]. They } \\
\text { have a professional for this } \\
\text { [lobbying/CPA] and international } \\
\text { support. They collect international } \\
\text { benchmarks; they hire consultants to } \\
\text { write policy papers, and even } \\
\text { legislative proposals." (Respondent, } \\
\text { Subsidiary11) }\end{array}$ & $\begin{array}{l}\text { "Hungarian companies do not } \\
\text { have political departments, not } \\
\text { even a person, who does it." } \\
\text { (Respondent, Local 9) } \\
\text { Also: Respondent, Local 01; } \\
\text { Respondent, Local } 12\end{array}$ \\
\hline
\end{tabular}




\begin{tabular}{|c|c|c|c|}
\hline $\begin{array}{l}\text { Relational } \\
\text { capabilities }\end{array}$ & & & \\
\hline $\begin{array}{l}\text { Collective } \\
\text { relational }\end{array}$ & $\begin{array}{l}\text { Membership in } \\
\text { associations or } \\
\text { interest groups } \\
\text { Direct formal and } \\
\text { informal networks to } \\
\text { political decision- } \\
\text { makers (association } \\
\text { level) }\end{array}$ & $\begin{array}{l}\text { Collective } \\
\text { "If we look at the last two years, what } \\
\text { we could do - it is almost zero. There } \\
\text { was no openness for negotiations, no } \\
\text { cooperation. There is no way of } \\
\text { entering [networks around the } \\
\text { government]." (Respondent, } \\
\text { Subsidiary14) } \\
\text { Also: Respondent Subsidiary } 2\end{array}$ & $\begin{array}{l}\text { Collective } \\
\text { "We can do lobbying through the } \\
\text { engineering association that } \\
\text { represents individuals, but we are } \\
\text { also members of consultant } \\
\text { engineers, the Hungarian chamber } \\
\text { of commerce. We believe it is } \\
\text { very important to be represented } \\
\text { on events. Everything depends on } \\
\text { personal contacts, you never } \\
\text { know. "(Respondent, Local 1) } \\
\text { Also: Respondent, Local 16; } \\
\text { Respondent, Respondent, Local 5, } \\
\text { 10; Respondent, Local 6) }\end{array}$ \\
\hline $\begin{array}{l}\text { Personal } \\
\text { relational }\end{array}$ & $\begin{array}{l}\text { Direct formal or } \\
\text { informal contacts } \\
\text { with political } \\
\text { decision-makers } \\
\text { (individual level) } \\
\text { CEO's professional } \\
\text { networks }\end{array}$ & $\begin{array}{l}\text { Personal } \\
\text { "I know a lot of decision-makers. I } \\
\text { organize meetings between leading } \\
\text { decision-makers like ministers and } \\
\text { state secretaries and the management of } \\
\text { my company. "(Respondent, } \\
\text { Subsidiary11) }\end{array}$ & $\begin{array}{l}\text { Personal } \\
\text { "Therefore, we have to have good } \\
\text { contacts with the state. We know } \\
\text { everybody. This is a small } \\
\text { country. "(Respondent, Local 10) } \\
\text { Also Respondent, Local0 } 6\end{array}$ \\
\hline
\end{tabular}

As the Orbán government consolidated its power - notably with the constitutional amendments of 2013 and after the re-election in 2014, the regime adopted increasingly authoritarian features moving the country towards a more particularistic relationship-based system characterized by discontinuous political risk; a process that can be termed “institutional backsliding".

As institutional pressures to engage in relationship-based exchanges became stronger, the "institutional fit" between political capabilities transferred from the subsidiaries' parent and the host environment decreased, reducing thus the value of these capabilities. Thus, CEOs of subsidiaries are losing some of their influence, notably due to the increasing nationalism of the government:

"First they [MNEs] need to find a good CEO, it is rare that a foreigner is allowed in this." (Respondent, Subsidiary10) 
Faced with discontinuous political risk, even the strategy of hiring local CEOs to establish political ties with the government has become less efficient due to the constantly and arbitrarily changing formal and informal rules:

"[T]he problem [with hiring well-connected locals] is that they knew the old mechanisms. The new mechanisms under this government are different." (Respondent, Subsidiary10)

Simultaneously, subsidiaries' ability to engage in the new types of CPA required to cope with the increasingly relationship-based and authoritarian regime is limited by headquarter standards, creating a tension between "institutional-" and "organizational fit." Our interviews clearly show that during institutional backsliding, money has once again become an important political resource (Respondent, Local 7). While money is one of the most liquid and hence transferrable political resource (Bonardi, 2011), in the specific context of backsliding, MNE subsidiaries lack the capability of mobilizing it (at least overtly), due to home-country/parent pressures. Our interviews suggest that, subsidiaries' leeway in engaging in bribery to get access to the political arena appears more limited than domestic firms', because MNEs tend to have stronger anti-corruption standards and are potentially exposed to stronger scrutiny of home-country media and anti-corruption activists than domestic firms. In other words, the increasing misfit between the home institutional environment and the host environment, decrease the value of this political capability due to the lack of legitimacy of certain practices in the home country context. Thus, one respondent referred to the dilemma that "direct communication" with officials was important, but that he was reluctant to use such channels, because of what the company would have to offer in exchange (namely monetary payments):

"The official forum for lobbying is the [industry] association and they lobby with the public decision-makers. Of course, there are some personal negotiations beyond this forum. It is a dilemma for me as it may be useful to have more direct 
communication, but the question is what do we say, what do we offer."

(Respondent, Subsidiary4)

In this context, indirect forms of monetary transfers have emerged, which are less obviously contradicting Western subsidiaries' home country institutional pressures and can provide an alternative channel to bribes. The most usual ones are supporting specific charities selected by people close to the governing elite and contracting a consultancy firm specialized in public affairs, which then gains access to the political arena, without the subsidiary knowing how. One CEO described the way in which the consultancies treat the companies' requests for access as 'smoke and mirrors' (Respondent of Subsidiary5).

Moreover, despite of the increasing personalization and informalization of statebusiness relationships during institutional backsliding, the government has also established new - more closely state-controlled - formal ways for companies to engage with the authorities. The most important one is the so-called "strategic partnership" between firms and the government. As one respondent explained:

"The big change came with the signature of the strategic partnership with the government. [...] What these agreements can really help [with], is to build highest-level relationships. If I say that I have an issue they will arrange a meeting on the highest level. 2-3 times a year our European leader can meet the Minister and we get reassuring messages. We use this a lot more recently." (Respondent, Subsidiary 7)

Strategic partnerships thus provide a way for MNE subsidiaries to acquire (collective) relational political resources without having to resort to practices that are incompatible with home-country institutional pressures and parent company standards (e.g. Subsidiary15).

In summary, our interviews show that up to the election of Orbán as PM in 2010, the increasingly rule-based institutional environment allowed subsidiaries to leverage 
organizational and transactional political capabilities, which were available to them due to their being part of an MNE. Since at least 2013, however, the institutional environment in Hungary has once again become much less favorable to rule-based transactions, which has decreased the value of transactional capabilities, but also of collective relational ones, until they have become virtually worthless in a context of discontinuous political risk. The only remaining political resources that allow firms to have their voice heard in the political arena are particularistic, personal relationships with politicians and public officials close to the Orbán clan or outright bribery. Particularistic relationships are not transferable and MNEs may hence lose some of their competitive advantage compared to local companies. Bribery, on the other hand, constitutes an example where a very easily transferable capability (money) has lost its value for MNEs due to the increasing conflict between the need for "organizational fit" with home-country shaped capabilities and "institutional fit" with the host-country environment. Indeed, as the "financial incentive strategy" (Hillman \& Wan, 2005) moves away from campaign financing to less legitimate and even illegal forms, this capability has lost its value for MNE subsidiaries, because these practices clash with home country institutional pressures (e.g. anti-bribery norms and legislation). Our interviews show indeed that although, most subsidiaries seem to be aware of the "availability" of the necessary capabilities in the new environment, not all of them are able to acquire them. This suggests that the need for "organizational fit" constitutes an important roadblock to transferability and effective CPA. Yet, we also find that MNEs have found ways to develop alternative capabilities e.g. consultancy firms or "strategic agreements" with the government, which are considered legitimate in both home and host country. Our findings are summarized in Table 5. 
Table 5: Political capabilities and institutional context

\begin{tabular}{|c|c|c|c|c|c|c|c|}
\hline \multirow[t]{2}{*}{ Transition phase } & \multicolumn{2}{|c|}{ Institutional pressures } & \multirow[t]{2}{*}{$\begin{array}{c}\text { Type of } \\
\text { political risk }\end{array}$} & \multirow[t]{2}{*}{$\begin{array}{c}\text { Political } \\
\text { capabilities } \\
\end{array}$} & \multirow[t]{2}{*}{$\begin{array}{c}\text { Value of } \\
\text { capability } \\
\end{array}$} & \multicolumn{2}{|c|}{$\begin{array}{c}\text { Availability of } \\
\text { capabilities to.. }\end{array}$} \\
\hline & $\begin{array}{l}\text { Rule- } \\
\text { governed, } \\
\text { impersonal } \\
\text { exchange }\end{array}$ & $\begin{array}{l}\text { Relationship } \\
\text {-based, } \\
\text { personal } \\
\text { exchange }\end{array}$ & & & & MNE & $\mathrm{DF}$ \\
\hline \multirow{4}{*}{$\begin{array}{l}\text { Shift to rules- } \\
\text { based system } \\
(1989-2010)\end{array}$} & \multirow[t]{4}{*}{ Strong } & \multirow{4}{*}{$\begin{array}{l}\text { Moderate } \\
\text { (decreasing) }\end{array}$} & \multirow[t]{4}{*}{ Continuous } & Transactional & High & High & Low \\
\hline & & & & Organizational & High & High & Low \\
\hline & & & & $\begin{array}{l}\text { Collective } \\
\text { relational }\end{array}$ & High & Medium & High \\
\hline & & & & Personal relational & Moderate & Low & High \\
\hline \multirow{4}{*}{$\begin{array}{l}\text { Early Orbán } \\
\text { years }(2010-14)\end{array}$} & \multirow{4}{*}{$\begin{array}{l}\text { Moderate } \\
\text { (decreasing) }\end{array}$} & \multirow{4}{*}{$\begin{array}{l}\text { Moderate } \\
\text { (increasing) }\end{array}$} & \multirow[t]{4}{*}{ Continuous } & Transactional & Moderate & High & Low \\
\hline & & & & Organizational & High & High & Low \\
\hline & & & & $\begin{array}{l}\text { Collective } \\
\text { relational }\end{array}$ & Moderate & Low & High \\
\hline & & & & Personal relational & High & Low & High \\
\hline \multirow{4}{*}{$\begin{array}{l}\text { Backsliding } \\
(2014-17)\end{array}$} & \multirow[t]{4}{*}{ Weak } & \multirow[t]{4}{*}{ Strong } & \multirow[t]{4}{*}{ Discontinuous } & Transactional & Low & Low & High \\
\hline & & & & Organizational & Moderate & High & Low \\
\hline & & & & $\begin{array}{l}\text { Collective } \\
\text { relational }\end{array}$ & Low & Low & High \\
\hline & & & & Personal relational & High & Low & High \\
\hline
\end{tabular}

Our findings allow us to further extend the theory of political capabilities. Thus, they show that subsidiaries not only combine different types of capabilities - some transferred, others locally developed - but actively use transferable ones to develop relational ones. Thus, MNE subsidiaries "buy in" political relations by appointing well-connected individuals from the host country. Different types of capabilities can hence be combined to develop an effective CPA strategy. Yet, which capabilities are valuable and available to different firms depends on their inherent transferability, and on "organizational-" and "institutional fit."

Our interviews indicate that the meta-capability of leveraging transferable political capabilities to create relational ones allows subsidiaries to gain a competitive advantage over local firms whose relational capabilities are initially superior, but who lag behind MNE subsidiaries regarding organizational and transactional capabilities. We propose:

Proposition 1: MNEs will leverage transferable transactional and organizational political capabilities in the host country to locally develop "sticky" relational ones. In a situation of transition towards a more rule-governed system - where transactional 
capabilities are valuable - this provides MNEs with a competitive advantage compared to DFs.

However, the leveraging of these different types of capabilities will depend on the institutional pressures emanating from the host country's political context. During backsliding, pressures increase towards relationship-based personal exchanges and political risk becomes increasingly unpredictable and incalculable. As a result, the value of (personal) relational capabilities increases, that of transactional ones decreases. Thus, one respondent argued

"There are some [name of sector] leaders, who keep more permanent relationships with these institutions, and we can see that legislation is more beneficial for those who have better networks." (Respondent, Subsidiary4)

Subsidiaries adapt to these changes by incorporating more of the collective and personal relational capabilities into their localized political strategy compared to their transactional and organizational ones. We propose:

Proposition 2: MNEs adapt their CPA to the host country's institutional pressures by mobilizing different types of capabilities. As the institutional pressures move towards relationship-based exchanges, MNEs will incorporate more "sticky" relational capabilities into their host-country CPA, whereas when the institutional pressures move towards rule-governed exchanges, subsidiaries will rely more on transferable transactional and organizational capabilities.

Our findings also show that transferred capabilities can provide subsidiaries with a competitive advantage not by neatly fitting the host country institutional context, but by providing MNEs with complementary capabilities that local firms do not possess to the same extent. We therefore propose: 
Proposition 3: transference of political capabilities shaped by an institutionally very different home-country environment increase MNE subsidiaries' ability to adapt their CPA to the host country context by providing the company with a wider range of capabilities to draw from. While such transferred capabilities may not neatly fit the host context, they may complement locally developed capabilities in ways that lead to effective CPA and competitive advantage.

Yet, even the meta-capability of mobilizing transactional and organizational political capabilities to develop relational ones reach their limit when faced with an increasingly volatile institutional environment, where successful political activity requires personal access to a small elite, which often needs to be obtained by means that are incompatible with home country pressures. Indeed, the political capabilities required for effective engagement with the increasingly autocratic state are not (openly) supported by the headquarters. Therefore, the tensions created by institutional volatility continue to increase for subsidiaries to the point where home-country legitimacy requirements are not compatible with host-country requirements anymore. Here, the need to achieve "organizational fit" does become a roadblock to achieve "institutional fit" of CPA with the volatile host environment. We therefore propose:

Proposition 4: As "backsliding" of the host country's political context reaches a certain point, MNEs' ability to adapt will decrease due to their home-country's and parent company's legitimacy requirements.

The performance implication is that domestic firms may be better able to adapt to the backsliding environment, while MNEs are more constrained in the development of effective political strategies in that context, reducing their competitive advantage.

\section{Discussion and Conclusion}


By considering how simultaneous home- and host country institutional pressures create a dual challenge for subsidiaries to achieve both "organizational-" and "institutional fit," our study makes an important contribution to the understudied question of how institutional differences across countries shape MNE political activities (Doh et al., 2012: 27; Liedong et al., 2015). We argue that further developing the "fit paradigm" (White et al., 2018) as applied to CPA, requires us to incorporate two dimensions into existing typologies of political capabilities, namely the varying transferability/stickiness of political capabilities and the contingency of their value in volatile political environments ("institutional fit").

We focus on the case, where the home environment is stable and rule-governed, while the host country environment is relationship-based and characterised by a shift to increasingly discontinuous political risk. We find that subsidiaries do not merely adapt to relationshipbased contexts by engaging in relational strategies (Luo and Zhao, 2013), but design a localized "combined" political strategy that combines transferred political capabilities with locally developed ones. This finding is in line with previous literature on transference of practices (Gamble 2010). This is because not all political capabilities are easily transferrable from home to host country and because some that are transferrable may not be valuable in certain host environments, leading to a need for subsidiaries to develop them locally. Interestingly, we also find that subsidiaries leverage parent organizational- and transactional capabilities to locally develop relational ones. As such, our study complements previous research that found that emerging market MNEs can transfer capabilities they developed to cope with a politicized economy in their home system to relatively similar host contexts (Carney et al., 2016). This has been termed the "adversity advantage" of MNEs from homecountries with weak institutional environments (cf. Ramamurti, 2009). Our findings suggest, however, that in certain circumstances, MNE political capabilities developed in institutionally different, more rule-governed, home countries can provide firms with complementary 
transactional and organizational political capabilities, which in combination with newly acquired, relational capabilities allow them to develop effective CPA. Advanced country MNEs therefore possess a "prosperity advantage" when developing CPA for a relational context.

Yet, our framework also suggests that the value of transactional and certain types of organizational capabilities will decline when the institutional environment moves away from a rule-governed one towards a relationship-based one and when political risk becomes less predictable or discontinuous (Oh and Oetzel, 2017) as is the case in a phase of "backsliding." Based on the transferability-value dilemma, whereby transferable and hence easily available capabilities for subsidiaries are increasingly less valuable in relational environments characterized by discontinuous risk, we would expect subsidiaries have to increasingly rely on locally-developed personal relational capabilities to achieve "institutional fit." However, this has implications for "organizational fit" of the subsidiary strategy with capabilities that are shaped by a "rule-governed" home environment. Here, the dual challenge of "organizational-" and "institutional fit" becomes increasingly an obstacle to successful adaptation to the volatile environment. Therefore, our study also has implications for the theory of volatile institutional environments (Darendeli and Hill, 2016; Oh and Oetzel, 2017). It shows that up to a point, MNE subsidiaries are exceptionally well-equipped to deal with such environments due to their capability to mobilize different types of capabilities to formulate effective CPA. Yet, there may be a point where the environment may become too unpredictable for transactional and collective relational resources to have any value. This is where MNE subsidiaries may reach their limit of adaptability.

\subsection{Limitations and future research implications}

One limitation of our study is that it is based on an extreme case. This was a conscious choice, as such cases are particularly revealing of important empirical phenomena. However, 
this raises the issue of the boundary conditions of our findings. We would expect that our insights are applicable to other post-socialist countries that have recently experienced phases of "backsliding" (e.g. Russia and Poland; cf. Orenstein 2013), but they may also be relevant for other cases where discontinuous political risk prevails. Future research should investigate in comparative fashion a wider range of such contexts.

Another limitation is that we did not distinguish differences in our MNEs subsidiaries home setting. This is because we focused on the contrast between rule-governed and relationship-based nature of home and host country and surmised that all Western countries are close to a fairly stable rules-based system in Peng's (2003) sense. Yet, some of them use relationships more extensively than others. This may provide MNE subsidiaries from such countries with certain resources and capabilities that make them particularly successful in adapting to relationship-based systems in emerging markets (see Porter 1990 for the case of Italian companies in developing countries).

Our study also relates to the question of "institutional duality" (Kostova and Roth, 2002). Previous research into institutional duality showed that MNEs can tap into capabilities from multiple local contexts and integrate them to create a range of competitive advantages (Kostova et al., 2008; Meyer et al., 2011; Regnér and Edman, 2014; Saka-Helmhout et al., 2016). Our findings suggest that whether institutional duality is a resource or a constraint for an MNE may depend on whether the capabilities required in a specific host context are transferable or not. Future research should more systematically conceptualize and investigate the link between institutional duality and transferability of capabilities.

\subsection{Managerial implications}

From a practitioner's point of view our study illustrates the importance of subsidiarylevel political strategy design and the role of subsidiaries' top management in this process. Our findings hint at the important tensions that emerge for foreign subsidiaries due to 
"backsliding." It indicates that developing relational capabilities of both the collective and increasingly - personal type seems key to a successful political strategy in such contexts. However, it becomes also clear that faced with a government that increasingly disregards formal channels of interest representation, foreign companies may face delicate ethical questions in crafting effective CPA. Therefore, effective CPA should not be done by host country senior management or the subsidiary in insolation (as it is generally the case), but needs to be coordinated with the parent company. Two issues are particularly important for effective host-country CPA: Firstly, the headquarters need to provide clear and effective guidelines about the limits of personal relational capabilities; Secondly, confidential and supportive communication channels between the subsidiaries top management and the headquarters are required to provide guidance on complex ethical decisions when dealing with host governments. 


\section{References}

Barnard, H., 2010. Overcoming the liability of foreignness without strong firm capabilities the value of market-based resources. J. Int. Manag, 16:2, 165-176, https://doi.org/10.1016/j.intman.2010.03.007

Beyers, J. Eising, R. \& Maloney, W., 2008. Researching Interest Group Politics in Europe and Elsewhere: Much We Study, Little We Know?, West Eur. Politics, 31:6, 1103-1128, doi: $10.1080 / 01402380802370443$

Boddewyn, J.J., 2016. International business-government relations research 1945-2015:

Concepts, typologies, theories and methodologies. J. World Bus. 51, 10-22. doi:10.1016/j.jwb.2015.08.009

Böhm, A, 2004. Theoretical Coding: Text Analysis in Grounded Theory. In Uwe Flick, Ernst von Kardoff, Ines Steinke (Eds). A Companion to Qualitative Research, 270-275.

London, Sage Publications

Bonardi, J.-P., 2011. Corporate political resources and the resource-based view of the firm. Strateg. Organ. 9, 247-255. Doi: https://doi.org/10.1177/1476127011417926

Bonardi, J.-P., Holburn, G.L.F., Vanden Bergh, R.G., 2006. Nonmarket Strategy Performance: Evidence From U.S. Electric Utilities. Acad. Manag. J. 49, 1209-1228. https://doi.org/10.5465/AMJ.2006.23478676

Brouthers, L.E., Brouthers, K.D., Werner, S., 2000. Perceived Environmental Uncertainty, Entry Mode Choice and Satisfaction with EC-MNC Performance. Br. J. Manag. 11, 183195. https://doi.org/10.1111/1467-8551.00160

Bryman, A. 2004. Social Research Methods. Oxford: Oxford University Press.

Carney, M., Dieleman, M., Taussig, M., 2016. How are institutional capabilities transferred across borders? J. World Bus. 51, 882-894. doi:10.1016/j.jwb.2015.12.002

Chen, D., Deakin, S., 2015. On Heaven's Lathe: State, Rule of Law, and Economic 
Development. Law Dev. Rev. 8, 123-145. https://doi.org/10.1515/ldr-2014-0031

Child, J., Rodrigues, S.B., Tse, K.K.-T., 2012. The Dynamics of Influence in Corporate CoEvolution. J. Manag. Stud. 49, 1246-1273. doi:10.1111/j.1467-6486.2012.01057.x

Cuervo-Cazurra, A., 2008. Better the devil you don't know: Types of corruption and FDI in transition economies. J. Int. Manag. 14, 12-27. https://doi.org/10.1016/j.intman.2007.02.003

Danisz, W.M., Chiaburu, D.S., Lyles, M.A., 2010. The impact of managerial networking intensity and market-based strategies on firm growth during institutional upheaval: A study of small and medium-sized enterprises in a transition economy. J. Int. Bus. Stud. 41, 287-307. doi:10.1057/jibs.2009.45

Darendeli, I.S., Hill, T.L., 2016. Uncovering the complex relationships between political risk and MNE firm legitimacy: Insights from Libya. J. Int. Bus. Stud. 47, 68-92. https://doi.org/10.1057/jibs.2015.27

Delios, A., Henisz, W.J., 2003. Policy uncertainty and the sequence of entry by Japanese firms, 1980-1998. J. Int. Bus. Stud. 34, 227-241. https://doi.org/10.1057/palgrave.jibs.8400031

Deng, G., Kennedy, S., 2010. Big Business and Industry Association Lobbying in China: The Paradox of Contrasting Styles. China J. 63, doi: https://doi.org/10.1086/tcj.63.20749196

Dieleman, M., Boddewyn, J.J., 2012. Using Organization Structure to Buffer Political Ties in Emerging Markets : A Case Study. Orga 33, 71-95. doi:10.1177/0170840611430595

Dieleman, M., Sachs, W.M., 2008. Coevolution of Institutions and Corporations in Emerging Economies: How the Salim Group Morphed into an Institution of Suharto's Crony Regime. J. Manag. Stud. 45, 1274-1300., doi: |https://doi.org/10.1111/j.14676486.2008.00793.x

Doh, J.P., Lawton, T.C., Rajwani, T., 2012. Advancing Nonmarket Strategy Research: Institutional Perspectives in a Changing World. Acad. Manag. Perspect. 26, 22-39., doi: 
https://doi.org/10.5465/amp.2012.0041

Dunning, J.H., Lundan, S.M., 2010. The institutional origins of dynamic capabilities in multinational enterprises. Ind. Corp. Chang. 19, 1225-1246. https://doi.org/10.1093/icc/dtq029

EBRD, 2005. Transition report (2005): Business in transition London. Transit. Rep.

Edwards, T., Sanchez-Mangas, R., Bélanger, J., Mcdonnell, A., 2015. Why are some subsidiaries of multinationals the source of novel practices while others are not? National, corporate and functional influences. Br. J. Manag. 26, 146-162. https://doi.org/10.1111/1467-8551.12090

Edwards, T., Rees, C., Coller, X., 1999. Structure, Politics and the Diffusion of Employment Practices in Multinationals. Eur. J. Ind. Relations 5, 286-306.

Eisenhardt, K. 1989. Building Theories from Case Study Research. Acad. Man. Rev., 14 (4), 532-550. www.jstor.org/stable/258557

Feinberg, S., Hill, T.L., Darendeli, I.S., 2015. An institutional perspective on non-market strategies for a world in flux, in: Lawton, T.C., Rajwani, T.S. (Eds.), The Routledge Companion to Non-Market Strategy. Routledge, London, pp. 29-45.

Ferner, A., Edwards, T., Tempel, A., 2012. Power, institutions and the crossnational transfer of employment practices in multinationals. Hum. Relations 65, 163-187. https://doi.org/10.1177/0018726711429494

Flynn, B.B., Kakibara, S.S., Schroeder, R.G., Bates, K.A., Flynn, E.J., 1990. Empirical Research Methods in Operations Management. J. Oper. Manag. 9, 250-284., doi: https://doi.org/10.1016/0272-6963(90)90098-X

Frynas, J.G., Mellahi, K., Pigman, G.A., 2006. First Mover Advantages in International Business and Firm-Specific Political Resources. Strateg. Manag. J. 27, 321-345. 
doi:10.1002/smj.519

Gamble, J., 2010. Transferring organizational practices and the dynamics of hybridization: Japanese retail multinationals in China. J. Manag. Stud. 47, 705-732. https://doi.org/10.1111/j.1467-6486.2009.00876.x

Getz, K.A., Oetzel, J., 2009. MNE strategic intervention in violent conflict: Variations based on conflict characteristics. J. Bus. Ethics 89, 375-386. https://doi.org/10.1007/s10551010-0412-6

Greskovits, Béla, 2015. The Hollowing and Backsliding of Democracy in East Central Europe. Global Policy, 6, 1, https://doi.org/10.1111/1758-5899.12225

Griffin, J.J., Dunn, P., 2004. Corporate Public Affairs: Commitment, Resources, and Structure. Bus. Soc. 43, 196-220. doi:10.1177/0007650304266277

Hadjikhani, A., \& Ghauri, P. N. 2006. Multinational Enterprises and Their Lobbying Activities in the European Union. In L. Oxelheim (Ed.), Corporate and Institutional Transparency for Economic Growth in Europe. Amsterdam: Elsevier.

Harsányi, F.M., Schmidt, S., 2012. Creating a public affairs function in countries without a public affairs culture. J. Public Aff. 12, 86-97. doi: |https://doi.org/10.1002/pa.407

Henisz, W., Delios, A., 2004. Information or influence? The benefits of experience for managing political uncertainty. Strateg. Organ. 2, 389-421. doi:10.1177/1476127004047619

Hillman, A.J., Hitt, M.A., 1999. Corporate Political Strategy Formulation : A Model of Approach, Participation, and Strategy. Acad. Manag. Rev. 24, 825-842. doi:10.1093/afraf/adil23

Hillman, A.J., Keim, G.D., Schuler, D., 2004. Corporate Political Activity: A Review and Research Agenda. J. Manage. 30, 837-857. doi:10.1016/j.jm.2004.06.003

Hillman, A.J., Wan, W.P., 2005. The determinants of MNE subsidiaries' political strategies: 
evidence of institutional duality. J. Int. Bus. Stud. 36, 322-340.

doi:10.1057/palgrave.jibs. 8400137

Holbourn \& Zelner, 2010. Political capabilities, policy risk, and international investment strategy: evidence from the global electric power generation industry. Strat. Mgmt. J., 31: 1290-1315, doi: 10.1002/smj.860

Iankova, E., Katz, J., 2003. Strategies for political risk mediation by international firms in transition economies: the case of Bulgaria. J. World Bus. 38, 182-203. doi:10.1016/S1090-9516(03)00018-X

Jensen, R., Szulanski, G., 2004. Stickiness and the adaptation of organizational practices in cross-border knowledge transfers. J. Int. Bus. Stud. 35, 508-523. doi:10.1057/palgrave.jibs.8400107

King, B.G., Pearce, N.A., 2010. The contentiousness of markets: Politics, social movements, and institutional change in markets. Annu. Rev. Sociol. 36, 249-67. doi:10.1146/annurev.soc.012809.102606

Kostova, T., Roth, K., Dacin, M.T., 2008. Institutional Theory in the Study of Multinational Corporations: A Critique and New Directions. Acad. Manag. Rev. 33, 994-1006. https://doi.org/10.5465/AMR.2008.34422026

Kostova, T., Roth, K., 2002. Adoption of an organizational practice by subsidiaries of multinational corporations: Institutional and relational effects. Acad. Manag. J. 45, 215233. doi: $10.2307 / 3069293$

Kostova, T., 1999. Transnational Transfer of Strategic Organizational Practices: A Contextual Perspective. Acad. Manag. Rev. , 24, 308-324. https://doi.org/10.5465/amr.1999.1893938

Kostova, T., Zaheer, S., 1999. Organizational Legitimacy under Conditions of Complexity: The Case of the Multinational Enterprise. Acad. Manag. Rev. 24, 64-81., 
https://www.jstor.org/stable/259037

Kotabe, Masaaki \& Xiangwen Jiang, Crystal \& Y. Murray, Janet. (2011). Managerial Ties, Knowledge Acquisition, Realized Absorptive Capacity and New Product Market Performance of Emerging Multinational Companies: A Case of China. J. of World Bus. 46. 166-176. 10.1016/j.jwb.2010.05.005.

Lawton, T., Mcguire, S., Rajwani, T., 2013a. Corporate Political Activity: A Literature Review and Research Agenda. Int. J. Manag. Rev. 15, 86-105. doi:10.1111/j.14682370.2012.00337.x

Lawton, T., Rajwani, T., Doh, J.P., 2013b. The antecedents of political capabilities: A study of ownership, cross-border activity and organization at legacy airlines in a deregulatory context. Int. Bus. Rev. 22, 228-242. doi:10.1016/j.ibusrev.2012.04.001

Leuz, C., Oberholzer-Gee, F., 2006. Political relationships, global financing, and corporate transparency: Evidence from Indonesia. J. Financ. Econ. 81, 411-439. doi:10.1016/j.jfineco.2005.06.006

Liedong, T.A., Ghobadian, A., Rajwani, T., O’Regan, N., 2015. Toward a View of Complementarity: Trust and Policy Influence Effects of Corporate Social Responsibility and Corporate Political Activity. Gr. Organ. Manag. 40, 405-427. https://doi.org/10.1177/1059601114560064

Luo, Y., 2007. From foreign investors to strategic insiders: Shifting parameters, prescriptions and paradigms for MNCs in China. J. World Bus. 42, 14-34. doi:10.1016/j.jwb.2006.08.009

Luo, Y., Park, S.H.O., 2001. Strategic Alignment and Performance of Market-Seeking MNCs in China. Strateg. Manag. J. 22, 141-155.

Luo, Y., Zhao, H., 2013. Doing Business in a Transitional Society: Economic Environment and Relational Political Strategy for Multinationals. Bus. Soc. 52, 515-549. 
doi:10.1177/0007650309338365

Lux, S., Crook, T.R., Woehr, D.J., 2011. Mixing Business with Politics: A Meta-Analysis of the Antecedents and Outcomes of Corporate Political Activity. J. Manage. 37, 223-247. doi:10.1177/0149206310392233

Magyar, B., 2016. Post-Communist Mafia State. The Case of Hungary. Central European University Press, Budapest.

Martin, R., 2013. Constructing Capitalism: Transforming Business Systems in Central and Eastern Europe. Oxford University Press, Oxford.

McDonnell, M.-H., Werner, T., 2016. Blacklisted Businesses Social Activists' Challenges and the Disruption of Corporate Political Activity. Adm. Sci. Q. 1839216648953. doi:10.1177/0001839216648953

McGrath, C., 2005. Towards a lobbying profession: developing the industry's reputation, education and representation. J. Public Aff. 5, 124-135. doi:10.1002/pa.14

Meyer, K.E., Mudambi, R., Narula, R., 2011. Multinational Enterprises and Local Contexts: The Opportunities and Challenges of Klaus E. Meyer, Ram Mudambi and Rajneesh Narula. J. Manag. Stud. 48, 235-252. doi:10.1111/j.1467-6486.2010.00968.x

Meyer, K.E., Peng, M.W., 2016. Theoretical foundations of emerging economy business research. J. Int. Bus. Stud. 47, 3-22. doi:10.1057/jibs.2015.34

Miles, M. B. \& Huberman, M. A. 1994. Qualitative Data Analysis: An expanded sourcebook, Thousand Oaks: Sage.

Mondejar, R., Zhao, H., 2013. Antecedents to Government Relationship Building and the Institutional Contingencies in a Transition Economy. Manag. Int. Rev. 53, 579-605. doi:10.1007/s11575-012-0167-7

Nell, P.C., Puck, J., Heidenreich, S., 2015. Strictly limited choice or agency? Institutional duality, legitimacy, and subsidiaries ' political strategies. J. World Bus. 50, 302-311. 
Oetzel, J.M., Oh, C.H., 2014. Learning to Carry the Cat by the Tail: Firm Experience, Disasters, and Multinational Subsidiary Entry and Expansion. Organ. Sci. 25, 732-756. https://doi.org/10.1287/orsc.2013.0860

Oh, C.H., Oetzel, J.M., 2011. Multinationals’ Response to Major Disasters: How does subsidiary investment vary in response to the type of disaster and the quality of country governance? Strateg. Manag. J. 681, 658-681. https://doi.org/10.1002/smj

Oh, C.H., Oetzel, J.M., 2017. Once Bitten Twice Shy? Experience managing violent conflict risk and MNC subsidary-level investment and expansion. Strateg. Manag. J. 38, 714-731. https://doi.org/10.1002/smj

Oliver, C., Holzinger, I., 2008. The Effectiveness of Strategic Political Management: A Dynamic Capabilities Framework. Acad. Manag. Rev. 33, 496-520., http://www.jstor.org/stable/20159410

Orenstein, M.A., 2013. Reassessing the neo-liberal development model in Central and Eastern Europe, in: Resilient Liberalism in Europe's Political Economy. Cambridge University Press, Cambridge, pp. 374-402.

Peng, M.W., 2003. Institutional Transitions and Strategic Choices. Acad. Manag. Rev. 28, 275-296., https://doi.org/10.5465/amr.2003.9416341

Perkins, S.E., 2014. When Does Prior Experience Pay? Institutional Experience and the Multinational Corporation. Adm. Sci. Q. 59, 145-181. https://doi.org/10.1177/0001839214523603

Perry, C., 1998. Processes of a case study methodology for postgraduate research in marketing. Eur. J. Mark. 39, 785-802., https://doi.org/10.1108/03090569810232237

Porter, M. (1990). The Competitive Advantage of Nations. New York: Free Press.

Ramamurti, R., 2009. What have we learned about emerging market MNEs?, in: Ramamurti, R., Singh, J. V. (Eds.), Emerging Multinationals in Emerging Markets. Cambridge 
University Press, Cambridge, pp. 399-426.

Regnér, P., Edman, J., 2014. MNE institutional advantage : How subunits shape, transpose and evade host country institutions. J. Int. Bus. Stud. 45, 275-302. doi:10.1057/jibs.2013.66

Saka-Helmhout, A., Deeg, R., Greenwood, R., 2016. The MNE as a Challenge to Institutional Theory: Key Concepts, Recent Developments and Empirical Evidence. J. Manag. Stud. 53, 1-11. doi:10.1111/joms.12172

Sallai, D., 2013. European Union Lobbying and the Golden Cage of Post-Socialist Network Capitalism in Hungary. J. Common Mark. Stud. 51, 948-964. doi:10.1111/jcms.12029 Sallai, D., Schnyder, G., 2015. Strong State, Weak Managers : How Hungarian firms cope with autocracy 1-27, Centre for Business Research, University of Cambridge Working Paper no. 474, https://ideas.repec.org/p/cbr/cbrwps/wp474.html

Santos, Felipe M., and Kathleen M. Eisenhardt., 2009. Constructing Markets and Shaping Boundaries: Entrepreneurial Power in Nascent Fields. Acad. of Man. J., 52, 4, 2009, pp. 643-671. www.jstor.org/stable/40390310.

Sedelmeier, U., 2014. Anchoring Democracy from Above? The European Union and Democratic Backsliding in Hungary and Romania after Accession. J. Common Mark. Stud. 52, 105-121. https://doi.org/10.1111/jcms.12082

Siegel, J., 2007. Contingent Political Capital and International Alliances : Evidence from South Korea. Adm. Sci. Q. 52, 621-666. doi:10.2189/asqu.52.4.621

Stark, D., Bruszt, L., 1998. Postsocialist Pathways: transforming politics and property in East Central Europe. Cambridge University Press, Cambridge.

Sun, P., Mellahi, K., Thun, E., 2010. The dynamic value of MNE political embeddedness: The case of the Chinese automobile industry. J. Int. Bus. Stud. 41, 1161-1182. doi:10.1057/jibs.2009.94 
Sun, P., Mellahi, K., Wright, M., Xu, H., 2015. Political Tie Heterogeneity and the Impact of Adverse Shocks on Firm Value. J. Manag. Stud. 52, 1036-1063. doi:10.1111/joms.12165

Szulanski, G., 1996. Exploring internal stickiness: Impediments to the transfer of best practice within the firm. Strateg. Manag. J. 17, 27-43. doi:10.1002/smj.4250171105

Teece, D.J., Pisano, G., Shuen, A., 1997. Dynamic Capabilities and Strategic Management. Strateg. Manag. J. 18, 509-533., doi: https://doi.org/10.1002/(SICI)10970266(199708)18:7\%3C509::AID-SMJ882\%3E3.0.CO;2-Z

Thomson, S. and S. John, 2007. Public Affairs in Practice - A practical guide to lobbying. London, Kogan Page Ltd.

Van Schendelen, R., 2012. New trends of public affairs management at the EU level. J. Public Aff. 12, 39-46. doi:10.1002/pa.380

Walker, C. \& Habdank-Kolaczkowska, S. 2012. Nations in Transit - Fragile frontier: Democracies growing vulnerability in Central and Southeastern Europe. Freedomhouse available at: https:/www.freedomhouse.org/sites/default/files/Release\%20Booklet.pdf.

White, G.O., Fainshmidt, S., Rajwani, T., 2018. Antecedents and Outcomes of Political Tie Intensity: Institutional and Strategic Fit Perspectives. J. Int. Manag. 24, 1-15. https://doi.org/10.1016/j.intman.2017.06.001

Whitley, R., 2007. Business Systems and Organizational Capabilities. Oxford University Press, Oxford.

Whitley, R., Henderson, J., Czaban, L., Lengyel, G., 1996. Trust and Contractual Relations in an Emerging Capitalist Economy: The Changing Trading Relationships of Ten Large Hungarian Eneterprises. Organi 17, 397-420., doi: https://doi.org/10.1177/017084069601700303 
Witt, M.A., Kabbach de Castro, L.R., Amaeshi, K., Mahroum, S., Bohle, D., Saez, L., 2017. Mapping the business systems of 61 major economies. Socio-Economic Rev. 0, 1-34. https://doi.org/10.1093/ser/mwx012

Yin, R. 2003. Case study research: Design and methods. Thousand Oaks: Sage.

Young, M., Peng, M.W., Ahlstrom, D., Bruton, G.D., Jiang, Y., 2008. Corporate governance in emerging economies: A review of the principal-principal perspective: Review paper. J. Manag. Stud. 45, 196-220., doi:10.1111/j.1467-6486.2007.00752.x

Zajac, E.J., Kraatz, M.S., Bresser ', R.K.F., 2000. Modeling the Dynamics of Strategic Fit: A normative approach to strategic change. Strateg. Manag. J. 21, 429-453.

Zhang, Y., Zhao, W., Ge, J., 2016. Institutional duality and political strategies of foreigninvested firms in an emerging economy. J. World Bus. 51, 451-462.

doi:10.1016/j.jwb.2015.12.004 


\section{Appendix 1}

Figure 1: A model of subsidiary CPA in emerging markets

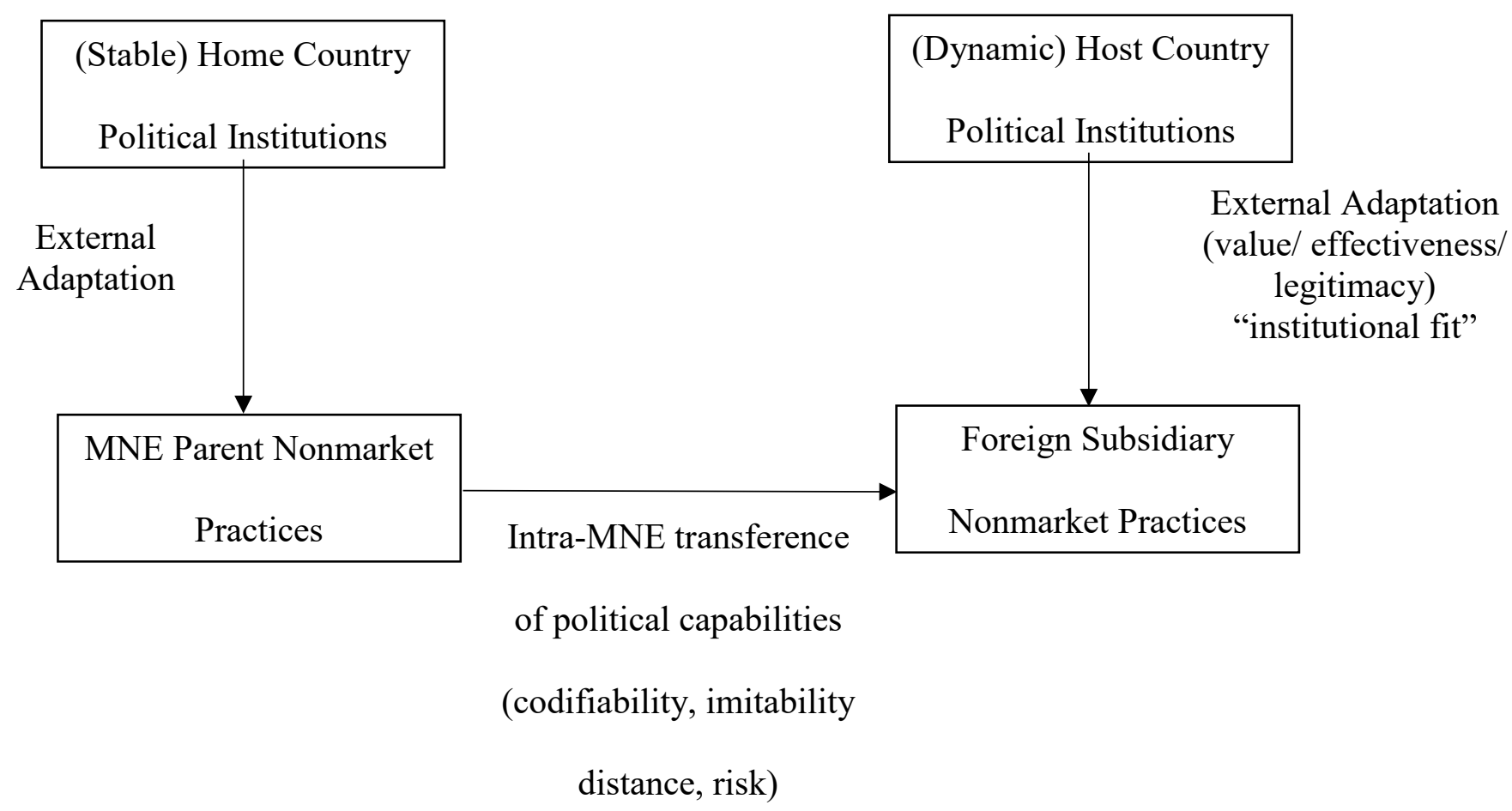

